\title{
Nurse's Perception of Family Presence during Dressing Change in the Adult: a Study in Burn Intensive Care Unit
}

\author{
Laxmi Shah ${ }^{1}$, Deepak Bagi \\ Sinha Health Foundation \\ Janakpur, Nepal
}

${ }^{1}$ Lecturer, Sinha Health Foundation, Janakpurdham, Nepal

\begin{abstract}
Background and Objectives: Burn injuries can be devastating to both the patients affected and the patients' families who support the injured person. In an effort to shield patients' family members from and anxiety-provoking experience and protect the patients from potential infections, burn units have historically restricted visitation during dressing change but evidence indicates that these restrictions contribute to patients' and family's dissatisfaction and to their knowledge deficit when it comes time to care for burn patients at home. Thus this study assess the nurse's perception of family presence during dressing change in the adult burn intensive care unit of selected tertiary care hospital in India.

Material and Methods: A Non- Experimental Descriptive Survey Design with evaluative research approach was used to evaluate the nurse's perception of Family Presence during dressing change in the Adult Burn Intensive Care Unit of KLES Dr. Prabhakar Kore Hospital and Medical Research Centre, Belagavi, India. A total of 30 nurses working in Adult Burn Intensive Care Unit (BICU) were selected by using the non-probability convenience method of sampling technique. A 5 points Likert scale was used for data collection.
\end{abstract}

Results: The study findings showed that, Majority 22 (73.3\%) of the nurses had performed dressing more than 11 times but $26(86.7 \%)$ of the nurses had never experienced family member in dressing room during dressing and 28 (93.37\%) of the nurses had never initiate family member during dressing change as well as majority 21 (70\%) of the nurses had never experience of family request to be on dressing room during dressing change. Majority $12(40 \%)$ of the nurses were disagree on family presence during dressing change, $10(33.3 \%)$ of the nurses were had neutral perception where as minority nurses 8 (26.7) had agree regarding family presence during dressing change.

Conclusion: The study revealed that majority of the nurses does not agree to have family member to be in room during dressing change even though presence of family members during dressing change will have a positive effect on patient, family, nurse, satisfaction with hospital care.

Key words: Family; Family Presence; Burn Intensive Care Unit; Perception; Burn

INTRODUCTION

Burn injuries can be devastating to both the patients affected and the patients' families who support the injured person.

Approximately 1.25 million people suffer a burn injury in the U.S. each year. Of this 
group, 51,000 require acute hospital admission. About 5,500 people die from burns and related inhalation injuries annually. India is the only country in the world where the burns was classified among the 15th leading causes of death. More than 7 lakhs burns patients being hospitalized and 1.2 lakhs death occurring annually due to burn injury every year where 1000000 people are moderately or severely burnt. The current statistical data for the year 2007 is 67 burn cases and is found to the admitted in Karnataka where the mortality rate is $7[1]$.

Burn injuries can be distressing to both the patients affected and the patients' families who support the injured person. Severe burn injuries can affect patients for a lifetime, leaving them with lifelong disabilities and chronic health conditions. In an effort to shield patients' family members from an anxiety-provoking experience and protect the patients from potential infections, burn units have historically restricted visitation during dressing change but evidence indicates that these restrictions contribute to patients' and family's dissatisfaction and to their knowledge deficit when it comes time to care for burn patients at home [2]. A major factor adding to the anxiety felt by patients and their families is the fear that health care providers withhold important information about a loved one [3].

A study conducted by Bailey JJ, shown that both patients and their families feel it is their right for family members to be present during procedures (family presence) and that both groups "would like the option to participate." Most family members believe that it is important to be present during their loved one's emergency procedures and that it is their right, duty, and obligation to be there [4]. Their presence at the bedside enables them to understand the severity of their loved one's condition and helps in removing doubt about the patient's condition by witnessing that everything possible is being done. Being present decreases family members' anxiety and fear about what is happening to their loved one and provides the means to communicate important information about the patient to the health care providers. It facilitates their need to be together and the opportunity to advocate for, comfort, protect, and support their loved one. Patients' families believe that family presence is helpful to the patient and themselves. Family members' presence allows them to experience a sense of closure. Family presence is reported to improve medical decision making, patient care, and communication with patients' family members [4].

In a study by Sproul et al, $87.8 \%$ of burn patients reported family support as very important to the patients' recovery [5]. In addition; Muangman et al reported that social support was a possible contributor to burn patients' in-hospital survival rates. In that study, $81 \%$ of patients who survived until discharge had some social support, compared with only $35 \%$ of non survivors $(P=.007)$. Family support can also decrease the risk of long-term psychosocial issues, such as financial burden, depression, posttraumatic stress disorder, and anxiety, in burn survivors. Similarly, adult patients who had family present during burn dressing changes had greater reduction in both pain and anxiety than did those who did not have family present $(P=.01)[6]$.

With increased survival rates and decreased length of stay, burn patients are being discharged from the hospital while still requiring complicated care. The patients' family and friends are identified as important 
sources of support and are often asked to perform daily dressing changes, including dressing removal, wound cleansing, and redressing, at home, with little or no preparation. Primary concerns patients identify when being discharged are recognition of wound complications and infections and treatment of wound pain. Discharge readiness is a complex issue that involves attention to patient-specific variables, including education, psychosocial evaluation, and home environment. In addition, family presence during dressing changes provided an opportunity to improve how care and education are delivered to patients and families in a burn unit [7].

The nurses have to play a vital role in rendering the immediate care to the client with burns otherwise it may lead to several other complications. So the Investigator felt the need to assess the perception of nurses regarding family presence during dressing change to assess the process of incorporating family presence during dressing changes and share the outcomes of the initiative. The goal is to illustrate the nurse's perception regarding family presence during burn dressing changes will add the body of knowledge on this issue.

Thus the study is to assess the nurse's perception of family presence during dressing change in the adult burn intensive care unit of selected tertiary care hospital, Belagavi.

\section{MATERIAL AND METHODS}

Research Approach: Evaluative approach and quasi experimental Descriptive Survey Design research was designed to conduct this research

Variables under the study: Dependent variables: Dependent variable was perception of nurses regarding family presence.

Demographic Variables: Personal characteristics that include age, gender, qualification, total years of experience, total years of experience BICU and attended in-service education.

Sample Size and Sampling Techniques: The sample size considered for the study was 30 Nurses working in Adult Burn Intensive Care Unit of KLES Dr. Prabhakar Kore Hospital and Medical Research Centre, Belagavi Karnataka. The sample for the present study was selected by a non probability Purposive sampling technique.

Exclusion Criteria: Nurses who were working at managerial level like supervisors, in-charge nurses were excluded.

Development and Description of Tool: The instrument used in this study was 5 points Likert scale on nurse's perception of Family Presence during dressing change in the Adult Burn Intensive Care Unit. The questionnaire was constructed in two sections with total of 25 questions with a 5-point Likert scale which was ranged from strongly disagree (1) to strongly agree (5). The risk benefit higher scores indicated a greater level of perceived benefit about family presence. The selfconfidence scale higher scores indicated a greater level of self-confidence in managing family presence during dressing change.

Procedure for data collection: The investigator obtained the formal permission of concerned authority of KLES Dr. Prabhakar Kore Hospital and Medical Research Centre, Belagavi for the project. The data was carried out from $7^{\text {th }}$ May 2016 to $14^{\text {th }}$ May 2016. 
Data collection and Analysis: The data was collected at Adult Burn Intensive Care of KLES Dr.Prabhakar Kore Hospital and Medical Research Centre, Belagavi, Karnataka, India. The collected data was organized, tabulated and analyzed based on the objectives of the study by using descriptive statistics ie, percentage, mean and standard deviation and inferential statistics such as chi square and t test. The chi square test was used to find out the association between demographic variables with nurse's perceptions on family presence. The findings of the study were presented in the form of tables and figure.

\section{RESULT}

Table 1 indicates that a majority $15(50 \%)$ of the nurse participants in the study belongs to the age of 26-30 years where as minority 9 (30\%) belongs to 25-30 years and only 6 (20\%) belong to $>35$ years age. Maximum $18(60 \%)$ numbers of nurses were male and remaining $12(40 \%)$ were female. Majorities $19(63.3 \%)$ of them were diploma holders and only $11(36.7 \%)$ were B.Sc. (N) graduates. Majority $12(40 \%)$ of the nurses had total clinical experience of 0-3 years, whereas $11(36.7 \%)$ has 3-6 years of experience and minimum $7(23.3 \%)$ had more than 6 years of experience. Majority $20(66.7 \%)$ of the nurses had total $0-3$ years of experience in BICU where as $7(23.3 \%)$ had 3-6 years in BICU experience and minimum $3(10 \%)$ had more than 6 years of experience in BICU. Majority 22 (73.3\%) of the nurses had performed dressing more than 11 times whereas $6(20 \%)$ of the nurses had only 1-5 times and only $2(6.7 \%)$ of the nurses had performed dressing for 6-10 times. Majority $26(86.7 \%)$ of the nurses had never experienced family member in dressing room during dressing whereas 3 $(10 \%)$ of the nurses had experienced family member in dressing room during dressing for 1-5 times and only 1 (3.3\%) nurse had experienced family member in dressing room during dressing for 6-10 times.

Figure 1: Frequency and Percentage distribution of nurse's perception scores regarding family presence during burn dressing change

Majority 28 (93.3\%) of the nurses had never initiate family member during dressing change whereas minority $1(3.3 \%)$ and 1 (3.3\%) nurse initiate family member for $1-5$ times and 6-10 times respectively. Majority $21(70 \%)$ of the nurses had never experience of family request to be on dressing room during dressing change whereas minority 1 $(3.3 \%)$ nurse had request for $6-10$ times and $4(13.3 \%)$ of the nurses had request from family to be in room for both 1-5 times and more than 11 times respectively member to be in dressing room during dressing change. 
Figure 1 revealed that, a majority $12(40 \%)$

of the nurses were disagreed on family

Table 1: Frequency and Percentage Distribution of Nurses According to the Demographic Variables $(\mathbf{n}=\mathbf{3 0})$

\begin{tabular}{|c|c|c|c|}
\hline S.N. & Demographic Variables & Frequency & Percentage \\
\hline $\begin{array}{l}1 . \\
1.1 \\
1.2 \\
1.3\end{array}$ & $\begin{array}{l}\text { Age (in year) } \\
20-25 \\
26-30 \\
>35\end{array}$ & $\begin{array}{c}9 \\
15 \\
6\end{array}$ & $\begin{array}{l}30 \\
50 \\
20\end{array}$ \\
\hline $\begin{array}{l}2 . \\
2.1 \\
2.2\end{array}$ & $\begin{array}{l}\text { Gender } \\
\text { Male } \\
\text { Female }\end{array}$ & $\begin{array}{l}18 \\
12\end{array}$ & $\begin{array}{l}60 \\
40\end{array}$ \\
\hline $\begin{array}{l}3 . \\
3.1 \\
3.2 \\
3.3\end{array}$ & $\begin{array}{l}\text { Professional qualification } \\
\text { Diploma nurses } \\
\text { Graduate nurses } \\
\text { Masters nurses }\end{array}$ & $\begin{array}{c}19 \\
11 \\
0\end{array}$ & $\begin{array}{c}63.3 \\
36.7 \\
0\end{array}$ \\
\hline $\begin{array}{l}4 . \\
4.1 \\
4.2 \\
4.3\end{array}$ & $\begin{array}{l}\text { Total years of experience } \\
0-3 \text { years } \\
3-6 \text { years } \\
>6 \text { year }\end{array}$ & $\begin{array}{c}12 \\
11 \\
7\end{array}$ & $\begin{array}{c}40 \\
36.7 \\
23.3\end{array}$ \\
\hline $\begin{array}{l}5 . \\
5.1 \\
5.2 \\
5.3\end{array}$ & $\begin{array}{l}\text { Total year of experience in BICU } \\
0-3 \text { years } \\
\text { 3-6 years } \\
>6 \text { years }\end{array}$ & $\begin{array}{c}20 \\
7 \\
3\end{array}$ & $\begin{array}{c}66.7 \\
23.3 \\
10\end{array}$ \\
\hline $\begin{array}{l}6 . \\
6.1 \\
6.2 \\
6.3 \\
6.4\end{array}$ & $\begin{array}{l}\text { Dressing change performed } \\
\text { Never } \\
\text { 1-5 times } \\
\text { 6-10 times } \\
\text { More than 11times }\end{array}$ & $\begin{array}{c}0 \\
6 \\
2 \\
22\end{array}$ & $\begin{array}{c}0 \\
20 \\
6.7 \\
73.3\end{array}$ \\
\hline $\begin{array}{l}7 . \\
7.1 \\
7.2 \\
7.3 \\
7.4\end{array}$ & $\begin{array}{l}\text { Experience to have Family member in } \\
\text { dressing room during dressing change } \\
\text { Never } \\
\text { 1-5 times } \\
\text { 6-10 times } \\
\text { More than } 11 \text { times }\end{array}$ & $\begin{array}{c}26 \\
3 \\
1 \\
0\end{array}$ & $\begin{array}{c}86.7 \\
10 \\
3.3 \\
0\end{array}$ \\
\hline $\begin{array}{l}8 . \\
8.1 \\
8.1 \\
8.3 \\
8.4\end{array}$ & $\begin{array}{l}\text { Initiate family member During dressing } \\
\text { change } \\
\text { Never } \\
1-5 \text { times } \\
6-10 \text { times } \\
\text { More than } 11 \text { times }\end{array}$ & $\begin{array}{c}28 \\
0 \\
1 \\
1\end{array}$ & $\begin{array}{c}93.3 \\
0 \\
3.3 \\
3.3\end{array}$ \\
\hline $\begin{array}{l}9 . \\
9.1 \\
9.2 \\
9.3 \\
9.4\end{array}$ & $\begin{array}{l}\text { Requests from family to be in during } \\
\text { dressing change room } \\
\text { Never } \\
1-5 \text { times } \\
6-10 \text { times } \\
\text { More than } 11 \text { times }\end{array}$ & $\begin{array}{c}21 \\
4 \\
1 \\
4\end{array}$ & $\begin{array}{c}70 \\
13.3 \\
3.3 \\
13.3\end{array}$ \\
\hline
\end{tabular}


$(33.3 \%)$ of the nurses were had neutral perception where as minority nurses 8 (26.7) had agreed regarding family presence during dressing change. So the figure revealed that majority of the nurses were not agreed to have family member to be in dressing room during dressing change.
Table 2 revealed that the calculated ChiSquare value was less than tabulated chi square value at $\mathrm{p}<0.05$ level with most of the vatiables. Thus, it indicate that there no significant association between nurse's perception and selected demographic variables

Table 2: Association between Nurse's perception on family presence with selected demographic variables $(n=30)$

\begin{tabular}{|c|c|c|c|c|c|c|c|}
\hline S.N. & Demographic Variables & Agree & Neutral & Disagree & $\begin{array}{c}\chi^{2} \\
\text { Cal }\end{array}$ & $\begin{array}{c}\mathbf{P} \\
\text { value }\end{array}$ & df \\
\hline 1. & $\begin{array}{l}\text { Age (in year) } \\
20-25 \\
26-30 \\
>35\end{array}$ & $\begin{array}{l}2 \\
5 \\
1\end{array}$ & $\begin{array}{l}3 \\
6 \\
1\end{array}$ & $\begin{array}{l}4 \\
4 \\
4\end{array}$ & 3.019 & 0.55 & 4 \\
\hline 2. & $\begin{array}{l}\text { Gender } \\
\text { Male } \\
\text { Female }\end{array}$ & $\begin{array}{l}4 \\
4\end{array}$ & $\begin{array}{l}8 \\
2\end{array}$ & $\begin{array}{l}6 \\
6\end{array}$ & 2.5 & 0.286 & 2 \\
\hline 3. & $\begin{array}{l}\text { Professional qualification } \\
\text { Diploma nurses } \\
\text { Graduate nurses }\end{array}$ & $\begin{array}{l}4 \\
4\end{array}$ & $\begin{array}{l}7 \\
3 \\
\end{array}$ & $\begin{array}{l}8 \\
4\end{array}$ & 0.861 & 0.650 & 2 \\
\hline 4. & $\begin{array}{l}\text { Total years of experience } \\
0-3 \text { years } \\
3-6 \text { years } \\
>6 \text { years }\end{array}$ & $\begin{array}{l}4 \\
3 \\
1\end{array}$ & $\begin{array}{l}4 \\
4 \\
2\end{array}$ & $\begin{array}{l}4 \\
4 \\
4\end{array}$ & 1.366 & 0.850 & 4 \\
\hline 5. & $\begin{array}{l}\text { Total year of experience in } \\
\text { BICU } \\
\text { 0-3 years } \\
\text { 3-6 years } \\
\text { >6 years }\end{array}$ & $\begin{array}{l}6 \\
2 \\
0\end{array}$ & $\begin{array}{l}8 \\
1 \\
1\end{array}$ & $\begin{array}{l}6 \\
4 \\
2\end{array}$ & 3.469 & 0.482 & 4 \\
\hline 6. & $\begin{array}{l}\text { Burn dressing performed } \\
\text { 1-5 times } \\
6-10 \text { times } \\
\text { More than 11times }\end{array}$ & $\begin{array}{l}1 \\
1 \\
6\end{array}$ & $\begin{array}{l}1 \\
1 \\
8\end{array}$ & $\begin{array}{l}4 \\
0 \\
8\end{array}$ & 3.303 & 0.508 & 4 \\
\hline 7. & $\begin{array}{l}\text { Experience Family member } \\
\text { during dressing room } \\
\text { Never } \\
\text { More than } 5 \text { times }\end{array}$ & $\begin{array}{l}7 \\
1\end{array}$ & $\begin{array}{l}9 \\
1\end{array}$ & $\begin{array}{c}10 \\
2\end{array}$ & - & - & \\
\hline 8. & $\begin{array}{l}\text { Initiate family member During } \\
\text { dressing change } \\
\text { Never } \\
\text { More than } 6 \text { times }\end{array}$ & $\begin{array}{l}8 \\
0\end{array}$ & $\begin{array}{c}10 \\
0\end{array}$ & $\begin{array}{c}10 \\
2\end{array}$ & - & - & \\
\hline 9. & $\begin{array}{l}\text { Requests from family to be in } \\
\text { during dressing change } \\
\text { Never } \\
1-5 \text { times } \\
\text { More than } 6 \text { times }\end{array}$ & $\begin{array}{l}5 \\
1 \\
2\end{array}$ & $\begin{array}{l}7 \\
2 \\
1\end{array}$ & $\begin{array}{l}9 \\
1 \\
2\end{array}$ & - & - & \\
\hline
\end{tabular}




\section{DISCUSSION}

There are many positive outcomes from having a strong family presence at the bedside through open visitation policies. Burn injuries can be distressing to both the patients affected and the patients' families who support the injured person. Severe burn injuries can affect patients for a lifetime, leaving them with lifelong disabilities and chronic health conditions. In an effort to shield patients' family members from an anxiety-provoking experience and protect the patients from potential infections, burn units have historically restricted visitation during dressing change but evidence indicates that these restrictions contribute to patients' and family's dissatisfaction and to their knowledge deficit when it comes time to care for burn patients at home [2]. A major factor adding to the anxiety felt by patients and their families is the fear that health care providers withhold important information about a loved one [3].

A study conducted by Bailey JJ, had shown that both patients and their families feel it is their right for family members to be present during procedures (family presence) and that both groups "would like the option to participate." A patient's family members want to know what is going on, have questions answered honestly, and see the patient frequently. Informational support has a positive correlation with families' satisfaction with care $(r=0.741 ; P<.001)$. Family members who participate in care perceive more respect, collaboration, and support than those who do not [4].

Present study revealed that majority 12 (40\%) of the nurses were disagree on family presence during dressing change, 10 (33.3\%) of the nurses were had neutral perception where as minority nurses 8 (26.7) had agree regarding family presence during dressing change. So the findings revealed that majority of the nurses do not agree to have family member to be in room during dressing change. The reason behind this finding could be inadequate knowledge, unskilled nurses. Similarly, anxiety of the family member may increase by seeing their loved one during dressing change procedure. The findings of the study were supported by; Herron S. study showed that, there were a higher percentage of respondents who did not favor family members being present [5]. Despite their disfavor of their family at bedside, many of the respondents felt that the presence of family members during resuscitation will have a positive effect on patient, family, nurse, and physician satisfaction with hospital care.In a study by Sproul et al, $87.8 \%$ of burn patients reported family support as very important to the patients' recovery [5]. In addition; Muangman et al reported that social support was a possible contributor to burn patients' in-hospital survival rates. In that study, $81 \%$ of patients who survived until discharge had some social support, compared with only $35 \%$ of non survivors $(P=.007)$. Family support can also decrease the risk of long-term psychosocial issues, such as financial burden, depression, posttraumatic stress disorder, and anxiety, in burn survivors. Similarly, adult patients who had family present during burn dressing changes had greater reduction in both pain and anxiety than did those who did not have family present $(P=.01)[6]$.

Family members who remain at the dressing time provide vital information about the patient and their presence increases communication and the continuity of care. Present family members also ensure a greater level of accountability demanded from the 
health care providers. When the patient and family desire open visitation, an increase in comfort and morale is observed in both the family and the patient, and the patient experiences more positive outcomes [2-5] which is in same line with our findings. our results indicate that even though presence of family member during burn dressing change improved communication, discharge readiness, and patient satisfaction and enhance the transition home but nurses acceptance were low and they were disagreed on family presence during dressing change.

\section{CONCLUSION}

The primary aim of this study was to assess the nurse's perception of Family Presence during dressing change in the Adult Burn Intensive Care Unit of selected tertiary care Hospital, Belagavi”. Nurses acceptance were low and they were disagreed on family presence during dressing change. Further more nurses are not only responsible for treating physical but also mental and spititual need of the patients and family member. Involving the family member can be an opportunity to educate family member in optimizing health care outcomes. Thus, it strongly recommended that nurses continue to investigate the incorporation of family presence during burn dressing changes.

Large scale study can be done for replication to standardize the self instructional module on digitalis therapy to prevent from toxicity. Similar study can be conducted with an experimental research approach having a control group. Further research should be completed pre and post dressing change both with family members and those patients that survive nicely after burn.
Researcher would like to thank all the participants of the study for their support and help.

\section{REFERENCES}

1. Backstro E. Family Members of Patients with Burns Experiences of a Distressful 2013. [online] https://uu.diva-portal.org/smash/get/diva2:6 54027/FULLTEXT01.pdf

2. Zeinab M. and Mohga A. Nurses' Knowledge and Practice for Prevention of Infection in Burn Unit at a University Hospital: Suggested Nursing Guidelines. Nursing and Health Science. Jul. - Aug. 2015; 4( 4): PP 62-69

3. Blakeney PE, Rosenberg L, Rosenberg M, Faber AW. Psychosocial care of persons with severe burns. Burns. 2008;34:433-440.

4. Bailey JJ, Sabbagh M, Loiselle CG, Bioleau J, mcvey L. Supporting families in the ICU: a descriptive correlational study of informational support, anxiety and satisfaction with care. Intensive Crit Care Nurs. 2010;26(2): 114-122.

5. Michelle E. Patient and family involvement in adult critical and intensive care settings: a scoping review 7 SEP 2015. [online] http://onlinelibrary.wiley.com/doi/10.1111/ $\underline{\text { hex.12402/abstract }}$

6. Muangman P, Sullivan SR, Wiechman S, et al. Social support correlates with survival with patients with massive burn injuries. J Burn Care Rehabil. 2005;26 (4):352-356.

7. Farrell RT, Gamelli RL, Sinacore J. Analysis of functional outcomes in patients discharged from an acute burn center. J Burn Care Res. 2006;27(2):189-194.

\section{Corresponding author:}

Ms. Laxmi Shah Lecturer, Sinha Health Foundation Janakpur Dham-8, Dhanusha, Nepal E-mail: laxmishah27@yahoo.com

\section{ACKNOWLEDGEMENTS}

